\title{
Hackathon for Learning Digital Theology in Computer Science
}

\author{
Emmanuel Awuni Kolog \\ University of Eastern Finland/School of Computing, Joensuu, FI-80101, Finland \\ Email: emmanuk@uef.fi \\ Erkki Sutinen and Eeva Nygren \\ University of Turku/Dept. of Information Technology, Turku, FI-20014, Finland \\ University of Eastern Finland/School of Computing, Joensuu, FI-80101, Finland \\ Email: erkki.sutinen@utu.fi;eeva.nygren@uef.fi
}

\begin{abstract}
Hackathon is an event where programmers and subject field specialists collaborate intensively in teams with the ultimate aim to create and design fresh ICT (information and communication technology) based solutions to a given task in a limited time. In this study, we analyzed students' perceptions and experience in a hackathon where they were to design a concept for an application aimed at people that are preparing for their own death. The hackathon was part of a Digital Theology (DT) course at the university for Computer Science (CS) students. 12 participated students were divided into three groups, where an assignment was presented to the groups to brainstorm and create a mock-up artefact suitable to tackle the challenge (assignment). By collecting data through questionnaires and interviewing the participants, we applied descriptive statistics rather than exploring into inferential statistics to analyze the data due to the limited number of students. In the end, the results show that the use of hackathon helped in achieving the learning goals of DT.The students expressed their satisfaction in the fact that it provided them with motivation to learn through practice. Also, students agreed that the event helped them to think collaboratively for a refined ideas. The overwhelming satisfaction expressed by the students goes to confirm that hackathon brings out the best creative skills from people through problem-solving.
\end{abstract}

Index Terms-Hackathon; Digital Theology; Computer Science Education; Trans-disciplinary Education.

\section{INTRODUCTION}

The field of Computer science (CS) is recognized as an area with systematic exploration of theories and methods underlying the development of computer systems based on efficient algorithms. Relatively, the field is seen by many students and CS teachers as a difficult area [1], especially from the area of computer programming [6]. This, however, highlights the need for effective teaching and learning methods in CS pedagogy.

Given the nature of a CS program, a considerable number of teaching and learning methods have been developed to induce CS students to cope [2]. That notwithstanding, there is still ongoing research largely focused on optimizing the existing methods or developing new and more effective teaching and learning methods to qualitatively improve the field. Consequently, the scholarship as a result of the findings of these studies, usually by computer science education researchers, need to help improve CS education [2]. CS, as an academic discipline, is a project-based discipline that accordingly require pragmatic approach in order to succeed.

Hackathon, an event-based practical learning method, is touted to promote creativity through hands-on practical projects [3]. Hackathon has existed for over a decade but is given less emphasis in terms of teaching and learning of CS. Though the concept has been employed by business organizations and other related sectors to tackle complex problems, its relevance in CS education should not be overlooked. Hackathon, if thoroughly explored in CS education, would provide practically-oriented teaching and learning.

\section{BACKGROUND}

The motivating idea of using hackathon was to facilitate and help students towards learning of DT through project-based learning approach. Given the scope of this work, we highlight on the concept of DT and hackathon in this Section.It will also delve into the challenges associated with trans-disciplinary CS education. These are discussed in Subsections A to C.

\section{A. Digital Theology}

To define DT, we need to look into the individual meaning of the words: Digital and Theology. On one hand, according to Oxford Dictionary [4], the term digital in Computer Technology involves anything relating to, using, or storing data or information in the form of digital signals. On the other hand, theology is the study of religious truths or divine things, which is usually associated with the study and analysis of the concepts of God and that of God's attributes [5]. Theology is taught as an academic discipline, usually at the universities and theological institutions. DT is therefore an integration of technology into the understanding of the concept of God and the nature of religious ideas. DT is an emerging discipline that straddles between theology and digital studies. Researchers have described DT as transdisciplinary field rather than multi-disciplinary. This is due to its close association with the study of digital humanities and the attitude of humans to the meaning and 
interpretation of God's attributes [7]. Though the field is well known in theology, it is gradually gaining grounds in CS education. For instance, Harvard University in the USA and other institutions are working towards embracing DT as a course in CS education. King's College University in the UK has even taken the lead to introduced $\mathrm{PhD}$ program in DT. These examples go to underpin the claim that the field is gradually taking roots.

The perception may be that religion is square-shaped philosophy and therefore unable to circle techno-society. Conversely, religion is part of the society and has an impact on the socio-economic development of a country. In line with this, Guiso et al. [7] describe certain 'societal attitudes as conducive to higher productivity and growth. Technology has come to stay with its usage being adopted to the fullest in almost all human activities. The use of the internet and its applications (such as Facebook, twitter and blog) to promote religious beliefs are on the ascendency. This implies that one does not only have to be physically present at a gathering to understand or learn religious beliefs as it is still the case in many parts of the developing countries. It is however worth noting that technology has made it possible for people to express their faith through digital technologies.

DT partly aims to facilitate the concepts of God and God's attributes. That is why secular problems which are connected to humanity bring to the fore the transdisciplinary nature of DT. Technology tries to bring different beliefs into social media, online world and new hardware inventions. This, in a way, makes it easy to reach out to many people, thereby creating new ways of promoting religious beliefs. Section 2.3 delves into the challenges associated with the implementation of transdisciplinary research. Fig. 1 shows a pictorial view of the of DT and its approach (Trans-disciplinary). It shows how the intersection of theology and digital studies bring forth to DT.

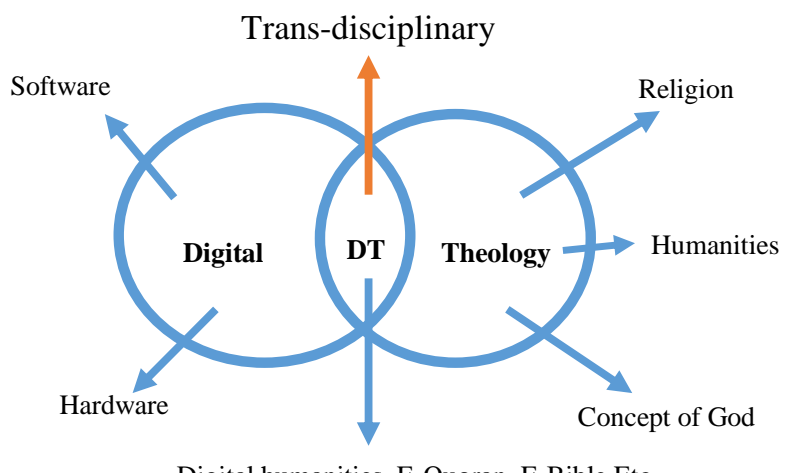

Digital humanities, E-Quoran, E-Bible Etc.

Fig.1. Pictorial representation of DT

\section{B. Hackathon}

People often assume hackathon as something associated with the literally usage of the term hacking. A friend of the first author who is not familiar with the discipline reacted as quoted below upon hearing the term hackathon for the first time.
"Who or what are you people going to hack, is this not illegal?"

This is not the actual meaning of the term. In fact, hackathon (also known as hack day, hack fest or codefest) emanated from a combination of the words hack and marathon. Hack is used in the sense of its exploratory programming while the marathon is associated with its timelines [18]. Hackathon, as defined by Calco and Veeck [8], is an event where computer programmers, developers and others involved in software and hardware development, including graphic designers, interface designers and project managers, collaborate intensively in teams with the ultimate aim of solving software-related problems. The term Hackathon is characterized by its innovativeness and creativity upon which a problem is tackled [9]. Hackathon events are driven by their venues and timelines. Usually, the timelines are tight and it is considered as a core component of assessing how well hackathon is organized in line with its objectives or purpose.

The concept of hackathons has existed for quite a long time before the late 1990 when the term hackathon was first used [8]. Since then, the original ideas have seen considerable variations depending on the discipline in which they are used. For instance, the concept of hackathon was employed in the field of marketing, for which the name "Markathon" [8] was given. As Briscoe and Mulligan [18] observed, the greatest value of hackathons is to provide opportunity for people from diverse background and as well provide a platform for long term links through collaborations.

Hackathon has gained prominence due to its relevance in evaluating how fast one is able to think critically and solve a problem under tight timelines. This can be supported by Selingo [10] who believes that employers now desire people or potential workforce to "come up with novel solutions to problems and better sort through information to filter out the most critical pieces". From 2000 to 2012, over 400 hackathons are reported to have taken place worldwide, spanning across several disciplines, including business and CS [11]. However, we could not find any literature to bolster the growth of hackathons from 2012. Given their wide acceptance in business organizations, we expect an exponential growth in hackathons after 2012. Most prominent among the organizers of these hackathons are Facebook, Google and Twitter, where hackathons are organized intermittently [8]. Hackathons are often organized with the intent of tackling more challenging software-related tasks.

Briefly, hackathon is seen as an innovative strategy adopted by employers or even the universities to select best candidate (s) suitable to undertake a project so that $\mathrm{s} / \mathrm{he}$ fits to some acceptable criteria.

\section{Challenges in trans-disciplinary CS education}

Trans-disciplinary (TD) education is an integrated field with a holistic focus on tackling real life problems [12]. Unlike inter-disciplinary approach, where different disciplines and methodology are jointly deployed, transdisciplinary research, though integrated, the approach 
cuts across other disciplines and transcends the boundaries of research within disciplines by addressing complex world problems [13]. Trans-disciplinary research, as viewed by Pohr and Hadorn [12] 'develops descriptive, normative and practice-oriented knowledge in order to help solve, mitigate or prevent life-world problems.' Trans-disciplinary solves complex problems yet life-world problems start from problem identification through to structuring and analyzing the problems at hand and to bringing the results into fruition [20]. With these steps, the approach takes into account the inclusion of stakeholders and scientists [14].

Introducing Trans-disciplinary in CS education comes with enormous challenges upon which Stock and Burton [14] observe that researchers in the field are skeptical about whether it can fully be achieved. This highlights the perceived challenges of trans-disciplinary research, especially in CS education. Given the fact that transdisciplinary research takes a holistic approach of solving complex problems, it complements but antagonistic to approaches of inter-disciplinary and multidisciplinary research approaches [13]. With this in mind, Pohr and Hadorn [8] identify the complexity of a perceived world problem, diversity of perspectives and promoting a common good as the challenges confronting the use and adoption of trans-disciplinary education. Also, Lang et al. [21] outlined challenges of trans-disciplinary research that undermines sustainability of trans-disciplinary projects. These challenges as outlined by Lang et al. [21] include fear to fail, lack of problem awareness, lack of legitimacy of trans-disciplinary outcomes, and vagueness and ambiguity of results.

One key factor that characterizes trans-disciplinary research education is the aim to tackle or solve complex world problems holistically. Conversely, the complexities of a perceived world problem tend to be a setback in the execution of successful trans-disciplinary research project in CS education. As Pohr and Hadorn [12] point out 'the trans-disciplinary challenge with complexity of problems is that of interrelating the broad range of factors to come up with an integrated understanding of the problem and integrated suggestions for dealing with the problem. ' In trans-disciplinary CS education, to tackle a problem takes a holistic look at the social, natural, technical and legal factors that constitute the problem. Pohr and Hadorn [12] believe that these factors have the tendencies to influence the eventual solution. In trying to understand these factors complicates the execution of trans-disciplinary projects.

CS education encompasses diverse areas with different views and ways of perceiving a problem. Likewise, perceived problems can be viewed and analyzed from different angles by different disciplines in line with the factors that constitute the problem. Every one may want his or her views and perspectives be heard loudly and by so doing intensifies the level of disagreements. This is a serious challenge, which might derail the timelines of trans-disciplinary research projects or approaches. This challenge brings about what Pohr and Hadorn [12] referred to as diversity of perspective. Through Pohr and Hadorn [12], Becker and Jahn [15] assert that to understand 'the diverse scientific and societal views of problems and engage in mutual learning and integration is a core challenge of Trans-disciplinary research'. Although the challenge of diversity in perspective could be resolved through a mutual exploration and clarification of perceived ideas [16] it still posed a challenge to transdisciplinary research, which makes it difficult to implement trans-disciplinary research projects to the fullest.

Promoting common good is one of the key conditions of trans-disciplinary research in CS education. Nonetheless, to come out with a common interest to all actors underscores its challenges. The proposed solution in trans-disciplinary research should aim at promoting satisfaction or common interest among disciplines by taking due cognizance of the factors that constitute the problem. Actors from different disciplines, in trying to find a solution to an existing world problem, tend to look at it from their respective ways of understanding the problem based on a body of knowledge, on which they are respectively well vested. Meanwhile, the perceived solution to a problem should be rooted in the agreement among the actors, thereby promoting common interest. This is what Clark [17, p.12] describes as "those that are widely shared within a community and demanded on behalf of the whole community." Hence, researchers perceive promoting common good, especially in CS, as a challenge in adopting trans-disciplinary in CS education.

\section{RESEARCH DESIGN}

The section takes a look at the research questions, the approach and the method on which the hackathon for DT was designed, organized and analyzed. The context and the mode by which data was collected are also elaborated in this section.

\section{A. Research questions}

1. How can a hackathon be organized to help students to learn DT in CS education?

2. What are the perceptions and experiences of students over the use of hackathon in learning DT?

\section{B. Context and participants}

DT was introduced as an entirely new course to undergraduate students (BSc and $\mathrm{MSc}$ ) in the school of Computing at the University of Eastern Finland in the first quarter of 2015/16 (September 2015) academic year. The hackathon was organized for the registered students as part of the requirements of the course, with the aim of helping students to learn DT. The hackathon part covered $30 \%$ of the total requirement of the course.

The course began with 19 students from 10 different countries across the globe. In line with the university's accepted practice some students freely discontinued while 12 students remained to continue with the course. At the beginning of the course, there was a need for preparations in order to meet the conditions for organizing a hackathon for the 12 participating students. They were from 10 
different countries viz. Tanzania, Czech Republic, Mexico, Nigeria, Nepal, Canada, Iran, Vietnam, China and Finland. Initially, they were skeptical about the event since most of them had no previous experience in it. Three of the students were female and the rest male.

To meet one of the core conditions of organizing effective hackathons (see Zheng, 2003), other experts were invited, among them a medical doctor, a theologian and an artist. The hackathon was held in a town called Kitee, an hour's drive from the University. The decision to organize the event away from the university was to give room for the participants to experience working outside their place of residence and to avoid domestic distraction.

\section{Research approach and methods}

Though several hackathons are reported to have taken place, few of them have reported their findings. With this, Table 1 summaries some hackathons that have been organized to induce learning. globally

Table 1. Hackathon experience

\begin{tabular}{|c|c|c|c|c|}
\hline Topic & Objective(s) & Participants and duration & $\begin{array}{l}\text { Data collection } \\
\text { and method }\end{array}$ & Findings \\
\hline $\begin{array}{l}\text { The } \\
\text { Markathon: } \\
\text { Adopting the } \\
\text { hackathon for } \\
\text { an introductory } \\
\text { marketing } \\
\text { project [8]. }\end{array}$ & $\begin{array}{lr}\text { To help } & \text { students learn } \\
\text { marketing } & \text { concepts } \\
\text { through } & \text { hackathon, } \\
\text { thereby } & \text { creating } \\
\text { marketing } & \text { project in an } \\
\text { organized } & \text { marketing } \\
\text { class. } & \end{array}$ & $\begin{array}{l}92 \text { students worked in } 26 \text { teams } \\
\text { Duration: organized in three } \\
\text { consecutive class periods with } \\
\text { each taking } 2 \text { hours }\end{array}$ & $\begin{array}{l}\text { Anonymous } \\
\text { paper and } \\
\text { pencil survey } \\
\text { (Questionnaire) }\end{array}$ & $\begin{array}{l}\text {-Through the event, students had a good time } \\
\text { of understanding marketing concepts and } \\
\text { business skills. It also encouraged students' } \\
\text { participation in the course. } \\
\text {-'The Markathon marketing project } \\
\text { contributed to their (students) attainment of } \\
\text { the skills spelled out in the } \\
\text { learning objective for this project [8]' } \\
\text {-Examples of innovation ideas include: an } \\
\text { app to provide support for students to car } \\
\text { pool a new interdisciplinary major. }\end{array}$ \\
\hline $\begin{array}{l}\text { Hackathon as } \\
\text { an informal } \\
\text { learning } \\
\text { platform. } \\
\text { (Ohio state } \\
\text { annual } \\
\text { hackathon } \\
\text { 2013) [3] }\end{array}$ & $\begin{array}{l}\text { To raise awareness of } \\
\text { technical talents at the } \\
\text { Ohio state, by giving } \\
\text { students the opportunity } \\
\text { to showcase their talents. } \\
\text {-The event also aimed at } \\
\text { providing a common } \\
\text { platform for } \\
\text { collaboration among } \\
\text { students and industrial } \\
\text { workers. }\end{array}$ & $\begin{array}{l}\text {-103 students } \\
-34 \text { teams } \\
\text { - All levels of students from } \\
\text { universities in the USA were } \\
\text { involved. } \\
\text {-Representatives from business } \\
\text { organizations. } \\
\text { - The participants came from } 8 \\
\text { different academic disciplines } \\
\text { including CS, Engineering, and } \\
\text { Geography. } \\
\text { Duration: } 36 \text { hours }\end{array}$ & $\begin{array}{l}\text {-Questionnaire } \\
\text { Observation }\end{array}$ & $\begin{array}{l}\text {-Students used the event to collaborate with } \\
\text { their colleagues from different disciplines } \\
\text { and also networked with representatives } \\
\text { from the industries. } \\
\text {-Students collaborated well to create } \\
\text { artefacts, an example is the creation of a } \\
\text { suicide prevention Android app. }\end{array}$ \\
\hline $\begin{array}{l}\text { Digital } \\
\text { Innovation: } \\
\text { The hackathon } \\
\text { phenomenon } \\
\text { [18] }\end{array}$ & $\begin{array}{l}\text { To discuss the potentials } \\
\text { and values of } \\
\text { hackathons. }\end{array}$ & $\begin{array}{l}\text { I50 programmers, including } \\
\text { students and teachers from all } \\
\text { over USA. } \\
\text {-Two hackathon cases from urban } \\
\text { prototyping London and NEM } \\
2013 \text { summit. } \\
\text { Duration: } 24 \text { hours for each } \\
\text { hackathon }\end{array}$ & $\begin{array}{l}\text {-Observation, } \\
\text { Questionnaire }\end{array}$ & $\begin{array}{l}\text {-Hackathon was realized in the study as a } \\
\text { successful tool for providing unique } \\
\text { networking community for people, } \\
\text { especially developers and students. Hence it } \\
\text { revealed that developers and students } \\
\text { continued their network after the event. }\end{array}$ \\
\hline $\begin{array}{l}\text { Hackathon as } \\
\text { an informal } \\
\text { learning } \\
\text { platform. } \\
\text { (Ohio state } \\
\text { annual } \\
\text { hackathon } \\
\text { 2014) [3] }\end{array}$ & $\begin{array}{l}\text { To raise awareness of } \\
\text { technical talents at the } \\
\text { Ohio state, by giving } \\
\text { students the opportunity } \\
\text { to showcase their talents. } \\
\text { Also, to provide platform } \\
\text { for collaboration among } \\
\text { students and industries. }\end{array}$ & $\begin{array}{l}-200 \text { students with } 59 \text { teams } \\
\text { formed. } \\
\text { - All levels of students from the } \\
\text { universities in the USA were } \\
\text { involved. } \\
\text { - The participants came from } 14 \\
\text { different academic disciplines } \\
\text { including CS, Engineering, } \\
\text { Business and Geography. } \\
\text { Duration: } 36 \text { hours }\end{array}$ & $\begin{array}{l}\text {-Questionnaire, } \\
\text { Observation }\end{array}$ & $\begin{array}{l}\text {-Students interacted well among themselves } \\
\text { and worked together to achieve a common } \\
\text { goal. } \\
\text {-Students were able to showcase their talents } \\
\text { through several other artefacts they created. }\end{array}$ \\
\hline $\begin{array}{l}\text { StitchFest: } \\
\text { Diversifying a } \\
\text { college } \\
\text { hackathon to } \\
\text { broaden } \\
\text { participation } \\
\text { and perception } \\
\text { in computing } \\
{[23] \text {. }} \\
\end{array}$ & $\begin{array}{l}\text { To use LilyPad Arduino } \\
\text { to design wearables and } \\
\text { to understand how } \\
\text { targeted recruitment, } \\
\text { thematic framing, space, } \\
\text { material distribution } \\
\text { impacted participation } \\
\text { and perception. }\end{array}$ & $\begin{array}{l}\text {-1,200 participants, but only } 33 \\
\text { were used for the data collection. } \\
\text { - Undergraduate and post } \\
\text { graduate students from USA, } \\
\text { Canada with CS, engineering art } \\
\text { and industrial design background. }\end{array}$ & $\begin{array}{l}\text {-Interview } \\
\text {-Photo } \\
\text { documentation } \\
\text { Approach } \\
\text {-Design-based } \\
\text { approach was } \\
\text { used for the } \\
\text { study. }\end{array}$ & $\begin{array}{l}\text { The study found that, intense and short } \\
\text { design experiences lived up to its potential } \\
\text { by engaging newcomers in designing a } \\
\text { compelling yet complex applications. This } \\
\text { generally changed the general perception of } \\
\text { the participants. }\end{array}$ \\
\hline
\end{tabular}




\begin{tabular}{|c|c|c|c|c|}
\hline $\begin{array}{l}\text { The } 2006 \\
\text { NESCent } \\
\text { Phyloinformati } \\
\text { cs Hackathon: } \\
\text { Afield report } \\
{[22] \text {. }}\end{array}$ & \begin{tabular}{lr}
\multicolumn{2}{l}{ Participants were tasked } \\
to integrate multiple \\
phylogenetic & software \\
tools into automated \\
workflows \\
hackathon.
\end{tabular} & $\begin{array}{l}\text {-26 software developers } \\
\text {-Developers were from New } \\
\text { Zealand and Japan. }\end{array}$ & $\begin{array}{l}\text {-Questionnaire } \\
\text {-Public wiki } \\
\text { from different } \\
\text { sources } \\
\text {-Use cases }\end{array}$ & $\begin{array}{l}\text {-Promoted creativity and equal participation. } \\
\text { Novice developers integrated well with the } \\
\text { experience developers to tackle the challenge } \\
\text { at hand. } \\
\text {-Revealed that hackathons helped in solving } \\
\text { software-related problems. Meanwhile, the } \\
\text { researchers indicated that hackathons have } \\
\text { been underutilized in scientific software } \\
\text { developments. } \\
\text {-The outcome improved the ability to } \\
\text { seemingly combine most popular } \\
\text { phylogenetic analysis programs into } \\
\text { complex workflow. }\end{array}$ \\
\hline $\begin{array}{l}\text { A hack for the } \\
\text { homeless: A } \\
\text { humanitarian } \\
\text { Technology } \\
\text { Hackathon } \\
\text { [24] }\end{array}$ & $\begin{array}{l}\text { The paper explored into } \\
\text { students' experiences } \\
\text { through hackathon, } \\
\text { which was meant to } \\
\text { develop a technology for } \\
\text { the homeless. }\end{array}$ & $\begin{array}{l}\text {-50 students with } 11 \text { teams were } \\
\text { involved. } \\
\text { - Organized in } 2 \text { phases } \\
\text { Duration: } 24 \text { hours }\end{array}$ & $\begin{array}{l}\text { Students were } \\
\text { made to answer } \\
\text { questions as the } \\
\text { project rolls on } \\
\text { (unstructured } \\
\text { form of } \\
\text { interview) }\end{array}$ & $\begin{array}{l}\text {-The event was successfully organized by } \\
\text { exposing students to the social impact of } \\
\text { technology, giving them practice with } \\
\text { development. } \\
\text {-It also provided students with directions and } \\
\text { collaborations in their ongoing projects. } \\
\text {-Given the successful organization of the } \\
\text { event, they relished to organize it again in } \\
\text { the future to address bigger tasks. }\end{array}$ \\
\hline
\end{tabular}

The event began with an opening presentation by the course professor and afterwards the task (challenge) was presented to the course participants. The students were to design an application for people that are preparing for own death. The other experts invited to the event were introduced to the participants with their roles clearly defined to them. The 12 participants were divided into three groups and an assignment, i.e., a challenge was presented to them. The challenge was a case for the students to brainstorm for ideas and design a plan (Mockup) with intent to implement the artefact after the hackathon. However, only those interested to continue would carry out the final implementation of their designs and for which they would be paid to execute the final project.

In order to motivate the students, they were assured that the best among them would be selected to be part of a bigger project. The main purpose of the event, as stated in Section 1, was to help students to learn to create a DT oriented application through hackathon. Each group was placed at different locations within the same premises. This was to avoid interferences, in order to allow the groups to work independently. The process of brainstorming for ideas to work on the design case and many other related activities lasted one day and student were tasked to present their case and mock-ups. Fig. 2 shows participants working as a group during the event.

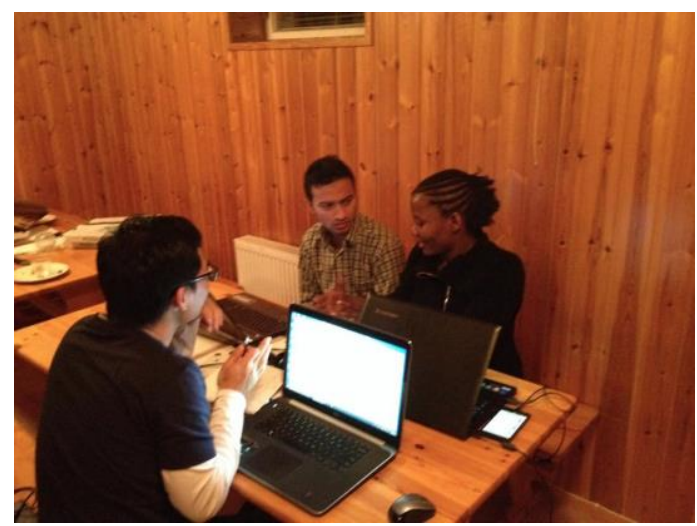

Fig.2. Participants working in group during the hackathon

\section{Collected data}

The data was collected from two sources. The first source was, while the event was ongoing the participants were asked some questions (interview) regarding the event. The questions were in the form of an unstructured interview, where the course professor and the invitees engaged in discussion with the participants. The discussion was mainly focused on understanding of the challenges facing the participants as well as directing them to overcome those challenges. Fig. 3 shows the invitees interacting with the participants as the hackathon was ongoing. The second source of data was from questionnaires consisting of open-ended and closed questions. The open-ended questions aimed at giving opportunity to the participants to respond to some of the questions subjectively while closed-ended questions were designed to use a five point Likert scale define as: 1completely disagree, 2- moderately disagree, 3somewhat disagree, 4-Nuetral, 5-somewhat agree, 6moderately agree, 7 - completely agree. In either case, the key purpose was to determine the perceptions of the students in the use of hackathon.

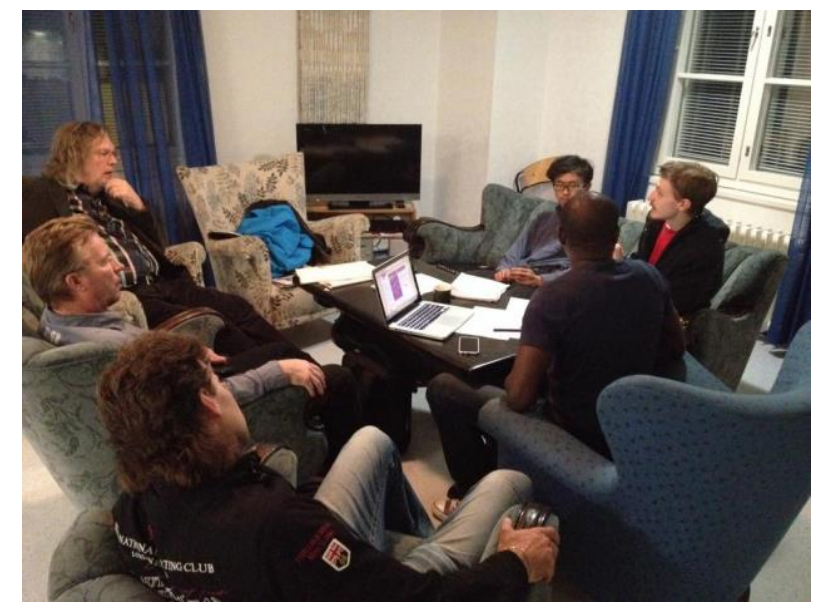

Fig.3. Invitees interacting with participants while the event was ongoing 


\section{DESIGN CASE FOR THE HACKATHON EXPERIENCE}

All the group participants were given the same challenge (case) during the hackathon. The design case was for students to design an artefact or an application that would help dying people to elaborate the reality of their coming death, including their perceptions, experiences and emotions. Before presenting the case, the course professor explained that many people had lost their lives without having the opportunity to reflect upon their last phases of their lives, especially those who were terminally ill and they would no longer survive. Actually, one of the invitees was given an opportunity to share with the participants a real life experience of her sister who had passed on.

The other invitees went round assisting the groups during the brainstorming session. The invitees were well chosen for the task since the design case was connected to them in one way or the other. For instance, the doctor assisted the participants on medical ethics while the artist assisted them with aesthetics in designing the artefact; the theologian assisted them on religious issues. Fig. 3 shows the participants working in groups as the invitees interacted with them.

The participants presented their findings and a mockup for the intended artefact. The presentation time was 20 minutes for each group. Students were told of the importance of individual member's contribution to the group presentation because that enabled them to understand the different grades allocated to them. The course professor and his assistant outlined the score criteria for each participant. The groups presented their ideas and mock-ups with regard to the design case.

Fig. 4 shows the participants looking on as the design case was presented to them. The Subsections below present the name and the ideas upon which each group presented their case during the poster presentation.

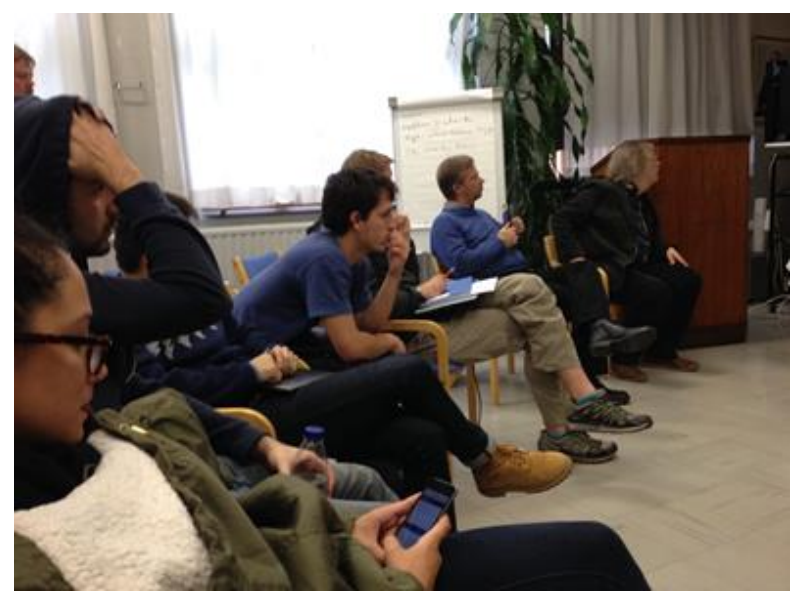

Fig.4. Participants looking on as the design case was presented to them.

\section{Group 1: Happy Walk}

Happy walk was the name given to the artefact by group 1. The group presenting their case explained that Happy Walk aims to help people stay motivated and positive during dark moments of their lives such as terminal illness. It tries to remind them to enjoy the little things in life by fulfilling small tasks that allow them to appreciate life. 'Share your story and be an inspiration to others' they said. According to the group, the user interface is meant to be simple and friendly, with no ads or overwhelming information. The starting menu of the application contains two main sections: Venture and Discover. A simple toolbar is displayed on the main menu, and all the interactions are done through swapping or clicking. Typing is not completely necessary as said by the group. The platform is to be launched on a mobile platform, specifically an Android and later on other platforms as well.

By analyzing the artefact design, the group incorporated the component that allows the intended people to interact with the application by playing music, videos and to interact with other people online. This fit well with the design case. However, we expected the group to find a way to incorporate a feature that would allow the use of the users' post for further analysis, such as sentiments and emotional analysis. Nevertheless, their input was appreciated. Based on their participation and contribution the group were scored from 25 to $30 \%$ depending on the individual performances.

Figs. 5 and 6 are screenshots of the mock-up design from the group. Some features of the happy walk platform are listed below.

- Music: Options to choose favorite songs.

- Religious quotes: Encouraging quotes (based on user's' faith) from Bible, Quran, etc.

- Funny cartoons which overlooks death.

- Motivating artworks with positives themes, such as 'Life is Eternal', 'Death is not the end' and 'Death is just a transformation'.
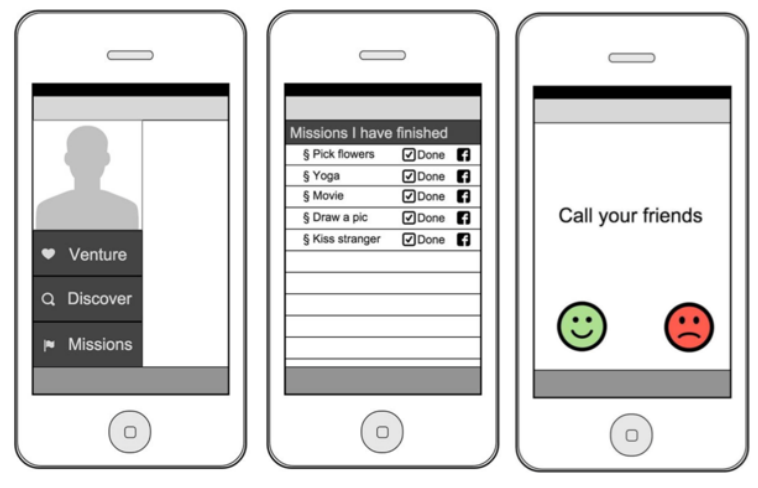

Fig.5. Screenshots of happy walk showing the main functionalities 


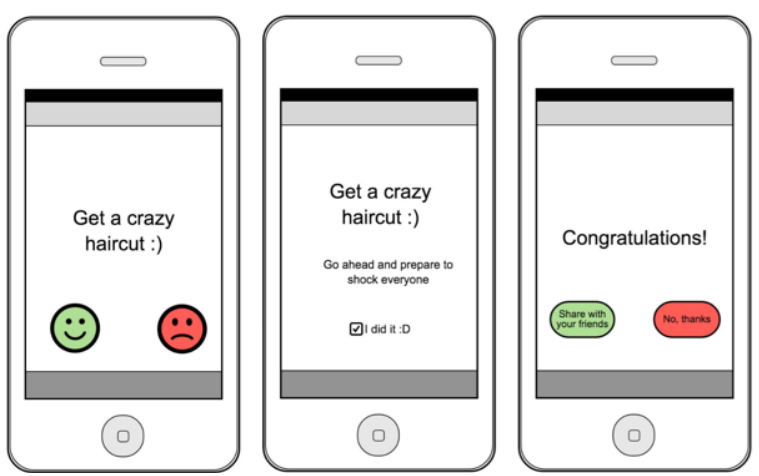

Fig.6. Happy walk page that provides opportunity for users to post content.

\section{Group 2: Close memo}

Close memo was the name group 2 gave to their artefact design. With their technique, after logging in, one is expected to see the interface that contains three buttons, with the inscription happy, unhappy and I don't know. According to the group, while the 'happy' part is for those who really have been declared to lose their lives but are happy to share their last moments, the 'unhappy' part aims at those in the same situation but unhappy about their situation and are willing to share their moments and thought with others. The 'I don't know' is those who do not really know about their feelings after being declared (by doctor) to die. The group intended to implement the platform as a mobile application.

The artefact designed by group 2 was in line with the design case. The group created a distinct feature in their design to cater for different states of terminally ill people. Though the design was considered value for use, the aesthetic view to enhance user experience was not so good. In general, the application was appreciated by the mark awarding team, of which a score from 25 to $28 \%$ was given depending on the individual performance. Fig. 7 represents the snapshot of the mock-up design from the group.

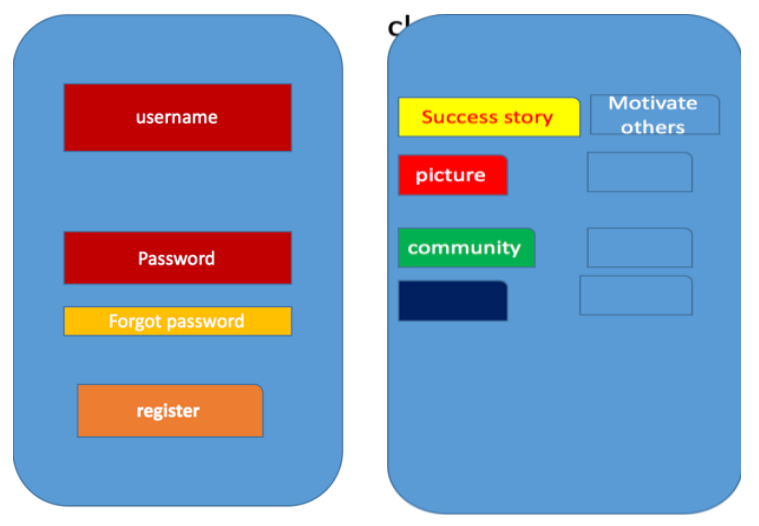

Fig.7. A snapshot of the login page and the main categories of the last moment platform.

Group 3: Last moment
Group 3 named their case as Last moment. According to the group, the name was curved based on the design case (challenge). The group described their ideas as follows:

'The soulless and stress plus too much thinking of someone who is seriously ill may take away the life before their demise. However, ICT has a role to make someone with such conditions to forget about death even though there is death. We designed web application platform to comfort their minds and help them save their last moment for their family and also for analysis

With their approach, they made provision for the sick people to share their last moment. The group in their presentation made provision for the data that would be stored in a database for sentiment and emotional analysis. The intent is for doctors and other interested health professionals to use the outcome as a guide to help other people with similar situations in the future.

The artefact was well designed and fitted into the design case. Given their presentation, we observed that the group also aimed at helping other people in the future by using the posts. And this, according to the group, would be achieved through the analysis of the data (post), using sentiment or emotion detection algorithms. That was a good and creative idea, but the group declined to make provisions for the protection of the data (data security) that would be collected for the analysis. The group were scored from 26 to $30 \%$ based on the individual performance. Fig. 8 is the snapshot of the mock-up application design from the group.

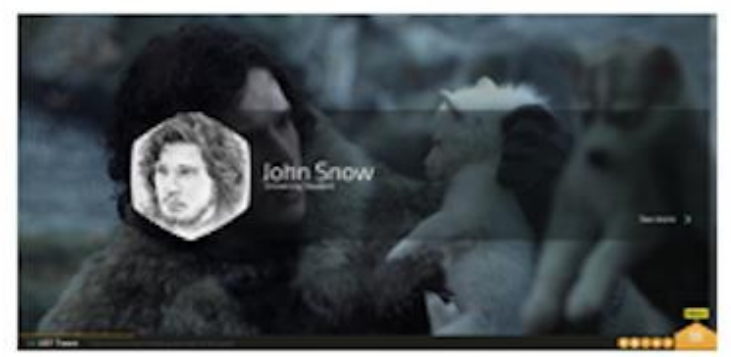

\section{Front page, with background picture, background music and user's name.}

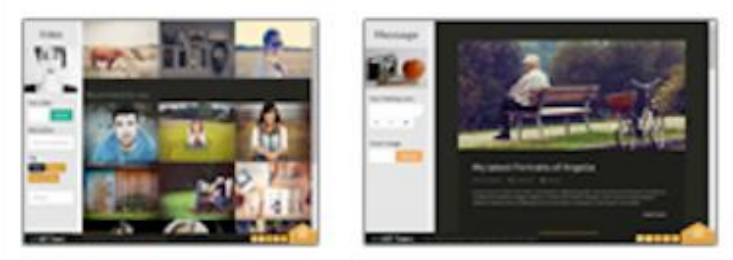

Media and blog posting

Fig.8. Screenshot of last moment design platform 


\section{RESULTS AND ANALYSIS}

The analysis of the data collected is discussed under three sections. These include the analysis from the learning point of view, the perceptions of the Hackathon arrangements and the challenges and limitations of the hackathon. The data analysis was carried out in two ways. First, the open-ended part of the questionnaire was analyzed using content analyses in line with interpretivists' philosophical paradigms. And the close part of the questionnaire was quantitatively analyzed by computing for the descriptive statistics (measures of central tendencies).

\section{A. Learning point of view}

From the survey, we partly aimed at gaining an insight into students' perception regarding the use of hackathon to learn DT. Unlike the usual studying hours, the hackathon was decided to be organized during a weekend from the Friday afternoon to the Saturday afternoon, and not all the students agreed with the scheduled date. As shown in Table 2, the majority of the students agreed $(M e a n=6)$ that the date slated for the event was good and helped them to focus fully on the project at hand. From the qualitative part of the collected data, most of students justified that they would be able to concentrate fully to the hackathon since there were no regular school time for the other courses.

The students, according to the survey, enjoyed every bit of the brainstorming session during the entire duration of the event (Mean =7). This may be because each group consisted of students from diverse cultural and academic backgrounds. One of the participants wrote that 'working with others from different cultural background was fantastic'. The qualitative responses from the students showed that the nature of the event actually urged them to augment their contribution. By comparing to the usual classroom teamwork, students agreed that hackathon helped brought out their best and sense of being more effective during the artefact crafting. One of the students wrote that:

II would keep postponing and would eventually not commit myself well in doing normal classroom's teamwork. Because of this I was very effective in the participation throughout."

From Table 2, the majority of the students agreed $($ Mean $=6)$ that the event was insightful and provided new ideas. This was probably due to fact that it helped them to think collaboratively (Mean $=6$ ), since the hackathon focused on the teamwork rather than one individual. Based on the subjective responses, students claimed that they could not have done better if the task was given out to them individually. Also, students conceded that they found DT as a difficult field from the initial stages of the course. This was because the course is an emerging field with less literature. Hence the organization of the hackathon coupled with the presence of the other invitees helped them to understand DT.

The event was successfully organized and gratifying (100\% of the students agreed). They expressed satisfaction in the fact that it provided them with motivation to learn through practice and as well afforded them the freedom to brainstorm for new ideas. One of the participants wrote that:

"It was hard to expect because I didn't know what to do. However I learnt much, I was able to generate an idea in our group and this made me happy."

After reviewing the data most of the students agreed that they had gained new experience since the event was entirely new to them.

During the interview session, we sought from the students about the impact of the invitees to the learning outcome of the design case. Students were enthusiastic about the idea of inviting other experts to be part of the event. This was because the students expressed their satisfaction on how certain questions were explained to them. According to the students, they learned a lot from the invitees. Since DT was new to most of the students, they could understand what the task was all about given their interaction with the invitees. It is not often the case to invite non-technical people to be part of such events. In our case, the intended idea was not just to craft an artefact but to learn DT alongside.

The students were of the view that attending a hackathon far from their respective homes was good idea and the practice need to be encouraged (Mean $=6$ ). They were satisfied that the environment in which the event was held met all their basic needs and that it made them comfortable to tackle the challenge at hand.

Overall, the students agreed that the event met its purpose $($ Mean $=6$ ) and expressed a strong willingness to be part of this event in the future. The overwhelming satisfaction expressed by the students goes to confirm that hackathon brings out the best creative skills from people through problem-solving [3]

Table 2. Students' perception of hackathon to their learning goals.

\begin{tabular}{lll}
\hline Question & Mean & SD \\
\hline Given my schedules, the date slated for the event was good and it helped a lot. & 6 & 2.0 \\
\hline I enjoyed sharing and brainstorming of new ideas & 7 & 0.8 \\
\hline I learned a lot of new ideas from the event & 5 & 0.8 \\
\hline The event has improve my level of collaborative thinking. & 6 & 1.3 \\
\hline I think the hackathon has served its purpose & 6 & 1.2 \\
\hline Doing hackathon far from home motivated my level of thinking & 6 & 0.9 \\
\hline NB: SD is Standard deviation & &
\end{tabular}




\section{B. The perceptions of the Hackathon arrangements}

Through the survey, the majority (83\%) of the participants had no knowledge of and previous experience in hackathon events, so there was a need to tell them on what to expect. It is in the light of this that a student wrote:

"To have an idea about hackathon and participate actively which I was able to do it with my team."

The duration and the design case were presented to the participants during the opening of the event. They had expressed misgivings about how the task could be completed within the given period but in the end, it was agreed that all the groups could complete their tasks within the period. Providing a challenge to the students rather than they carving their own design case prompted one of the students to write:

"The idea of bringing topic in the hackathon should continue as it helps people to think quickly in gathering the requirement. Also it helps to create a unique idea."

The venue of the event made provisions for the necessary things that the participants would need. This was to enable students to work effectively without distractions. There was food, drinks and recreation facilities such as swimming pool and sauna. The students said in an interview that they were satisfied with all of the amenities. A students wrote that:

"A remote and quiet place with plenty of rooms for group work made us feel really very comfortable and focus on our discussion better."
From Table 3, students appreciated the venue and the environment in which the event took place $($ Mean $=6)$. They also expressed satisfaction in the positive impact the environment had on the idea generation and that facilitated the creation of the artefact designs. Therefore, the majority of them believed a project-based approach such as hackathon was interesting with regard to achieving the learning outcomes. Students agreed (Mean $=5$ ) that such events should be repeated in the department, where they also proposed that such events should be organized in most of the CS courses.

Students felt that the duration given them to work on the design case was not enough, the students lamented in an interview. However, from the descriptive statistical analysis of the data from the questionnaires, students mildly (somewhat) disagreed $($ Mean $=3$ ) that the duration of the event was not enough. In either case, the students suggested that in future the duration of such events should be extended to allow more creativity and innovativeness. However, that did not take away the fact that the event was gratifying, since the students have pledged to suggest to their colleagues to participate in such events in the future (mean $=5$ ). Being in the same group with people from diverse cultural and linguistic background was a key to the idea generation $($ Mean $=6$ ). This afforded them the opportunity to think collaboratively for ideas that were more refined. Students and the invitees also collaborated well as the hackathon rolls on. We relish the thought that students would continue with the network, even after the hackathon. Networking afterwards would be healthy for their academic development.

Table 3. Students experience and perception during the artefact crafting

\begin{tabular}{lrr}
\hline Question & Mean & SD \\
\hline The venue of event was conductive for such a project & 6 & 0.9 \\
\hline The duration of the event was not enough for the project & 3 & 2.2 \\
\hline $\begin{array}{l}\text { Being in the same group with people from diverse cultural background helped me to know the } \\
\text { extent to which other people think and brainstorm }\end{array}$ & 6 & 1.4 \\
\hline I will advise my colleagues or anyone to join such an event in the future & 5 & 1.4 \\
\hline The hackathon was well organized & 7 & 0.9 \\
\hline
\end{tabular}

\section{Organizing hackathon: Challenges and limitations}

DT as a course is a novelty in CS at the University of Eastern Finland, as well as its CS department. Given this situation, there is the need to explore the challenges and limitations in organizing it. The purpose is to use the feedback gathered to improve any future organization of hackathon at the CS education.

The timing arrangement follow the same timing structures for all CS courses independently of their particular character and requirements. Normally the maximum time for any individual lecture of a course in the department is two hours but given the design nature of the DT course, it was evident that only two hours was insufficient for a design assignment that requires collaboration and creativity. This prompted the idea of holding a hackathon that required arrangement during a weekend because of other courses during the week.

Some of the students participating in the course resisted the hackathon date and they had to drop out of the course. Given this situation we understood that the students were not given prior information about the hackathon before the course started. Also, as we went interacted with the groups during the hackathon, the time allotted to the groups was not sufficient for the challenge to be completed. The students nonetheless tried their best to produce something worth considering.

It also emerged that inadequate preparation was made concerning the food because special needs of people with allergies were not taken into account and this caused dissatisfaction. In addition, based on the survey, students expressed dissatisfaction with insufficient time to sleep 
(rest), though hackathons are characterized by their tight timelines. Some of these challenges would be taken into consideration when organizing a future event. But overall, in spite of these challenges students said the event was well organized (Mean $=7$ ).

\section{DISCUSSION}

The scope of CS education keeps widening. Its scope has gone beyond the inter-disciplinary and multidisciplinary to trans-disciplinary approaches of solving problems. Trans-disciplinary education, which tries to tackle the world problems holistically brings to the fore the needed attention of modifying the way CS and other disciplines are taught. This, in effect help fades off the challenges which undermines trans-disciplinary education. Though several efforts have been taken to modify or develop new ways of teaching and learning, there is the need to rethink about how trans-disciplinary CS education could be improved. In CS, efforts ranging from learning through visualization and to virtual learning environments have been developed, but hackathon which has existed for more than a decade has less been used to support students to learn CS.

DT, a newly introduced course at the university is touted as trans-disciplinary hence the need to employ hackathon to help students learn the course. This is because hackathon was thought to be the best collaborative teaching method to help students to learn the course. Also, research has found that students have different learning abilities [25] and as a result it is often expedient to combine students to work in groups, thereby helping the weak ones to catch up.

As has been employed in this study, the event ended successfully and students were affirmative about the purpose of which the event was organized. The key objective of the event was to bring students onboard to brainstorm, appreciate each other's views and present a mock-up of their intended ideas with the intent of implementing their designs fully in the future. This could be attributed to the fact that students learnt new ways of thinking (collaborative) and brainstorming while working to arrive at viable yet plausible ideas for their artifact design.

Getting everyone in a group to agree on an idea comes with challenges [8], especially from people with diverse cultural backgrounds. Each group consisted of participants from different cultural and religious backgrounds given the nature of the course. This motivated their level of collaborative thinking. With this, students agreed to disagree in order to allow more creative ideas. Thus, cultural diversity of the students motivated the idea generation and the crafted designs. Given the cultural backgrounds of the participated students, the participated students justified their points or ideas based on their cultural and academic perspectives. This ensures a refined idea as the study had revealed in the qualitative responses to the questionnaires.

The majority of the students had no experience in hackathons and the event provided them with one. Not only did they participate in the event, they were active in the organizational process. Organizing hackathons to solve a problem requires that guidelines are well outlined to inspire creativity rather than muddling participants, as Calco and Veeck [8] observed. The event motivated students' participation. Students participated well in all the various stages of the event. We could however state that hackathon enhances students' participation in learning.

The outlined challenges and limitations were noted and would be considered in future hackathons. The finding from the study is that students were motivated in the use of hackathon in learning. This indicates that the application of hackathon to learn DT was well chosen and should be motivated. The artefacts crafted by the groups were deeply appreciated. This is because the crafted designs, in accordance with the challenge, seem to address the design case. This goes to confirm the impact the hackathon had on the students' level of thinking thereby fulfilling the purpose for which the event was organized. Indeed, one commented that: 'I enjoyed been part of this event.'

Though hackathon may have been explored mildly as a tool to teach and learn CS courses, its relevance to aiding students to learn cannot be overlooked. Based on our experience from the event, we relish the thought that hackathon should be intensified in CS education in order to motivate CS pedagogy. We recommend that in hackathons, if employed in CS education, experts from job-related environment should be invited. This intent would enhance students' understanding, participation and collaboration.

\section{CONCLUDING REMARKS}

In this study, we leveraged hackathon to help university students to learn DT. A survey was conducted with the use of questionnaires in order to collect feedback from the students, complemented with an unstructured interview. The aim of the survey was to find from the participants whether the purpose of the event was achieved.

The participated students were grouped into three teams. Each teams respectively brainstormed for ideas to craft the concept of a design case (challenge). After analyzing the collected data, we found out that the hackathon was gratifying and improved their way of thinking competitively and collaboratively with regard to working in groups from diverse cultural and social background.

The event was the first of its kind to most of the participated students, for which students have demonstrated their desire to be part of such event in the future. Students were of the common view that the hackathon achieved its purpose. With this, we found out that students participated effectively in the event which brought about networking and collaboration among themselves and the invitees. In future, the mock-up design would be developed and showcase to the scientific community. 


\section{ACKNOWLEDGEMENT}

We are grateful to the staff of kiteen kansanopisto at Kitee for providing us with the venue to host the hackathon. We appreciate the effort of the school of Computing of the University of Eastern Finland for sponsoring the event.

\section{REFERENCES}

[1] G. Robins, n.d 'Teaching Theoretical Computer Science at the Undergraduate Level: Experiences, Observations, and Proposals to Improve the Status Quo.' Retrieved from: <http://128.143.137.29/ robins/papers/Teaching_Theoreti cal_Computer_Science_at_the_Undergraduate_Level.pdf $>$ on $7^{\text {th }}$ March 2016.

[2] Final Report of the CSTA Curriculum Improvement. The New Educational Imperative: Improving High School Computer Science Education. Association for Computing Machinery, Inc (ACM), 2006.

[3] A. Nandi and M. Mandernach 'Hackathons as an Informal Learning Platform' Proceedings of SIGCSE '16, March 02 - 05, 2016, Memphis, TN, USA.

[4] Online Oxford dictionaries. Retrieved from: $<$ http://www.oxforddictionaries.com/definition/english/di gital?q=digital+> on $28^{\text {th }}$ February 2016.

[5] P. Michael, 'Theology'Bible.org. 2005.Retrieved from:<https://bible.org/article/what-theology $\geq$ on 7th March 2016.

[6] S. M. Abdel Rahman, B. AL-Syabi, E. Al Sharji, S. S. Al Kaabi,'The Reasons behind the Weakness of some Students in Programming Courses in the College of Applied Science, Ibri', International Journal of Modern Education and Computer Science(IJMECS), Vol.8, No.1, pp.48-54, 2016.DOI: 10.5815/ijmecs.2016.01.07

[7] L. Guiso, S. Paola and Z. Luigi 'People's Opium? Religion and Economic Attitudes' Journal of Monetary Economics. Vol. 50, No.1, pp. 225-282, 2003.

[8] OM. Calco and A. Veeck, 'The Markathon: Adapting the Hackathon Model for an Introductory Marketing Class Project' Marketing Education Review, Vol. 21, No. 1, pp. 33-38, 2015.

[9] S. Zheng, 'The fundamentals behind a successful hackathon' Tok Box Blog, Retrieved from <http://www.tokbox.com/blog/the-fundamentals-behinda-successful-hackathon/> on $18^{\text {th }}$ Feb. 2016.

[10] J. Selingo, 'Skills gap? Employers and colleges point fingers at each other' The Chronicle of Higher Education, $2012 . \quad$ Retrieved from <http://chronicle.com/blogs/next/2012/09/12/skills-gapemployers-and-colleges-point-fingers-at-each-other/ > on $18^{\text {th }}$ Feb. 2016.

[11] S. Leckert, 'The hackathon is on: Pitching and programming the next killer app.' Wired. Com, 2012. Retrieved from: <http://www. wired.com/magazine/2012/02/ff_hackathons/all/1> on $17^{\text {th }}$ February 2016.

[12] C. Pohl and G.H. Hadorn, 'Methodological challenges of trans-disciplinary research' Natures Sciences Sociétés. Vol. 16 No. 2, pp.111-121, 2008.

[13] B. Nicolescu, 'The trans-disciplinary evolution of learning' Symposium on Overcoming the Underdevelopment of Learning at the Annual Meeting of the American Educational Research Association, Montreal, Canada, 1999.
[14] P. Stock and R.J Burton, 'Defining terms for integrated (multi-inter-trans-disciplinary) sustainability research.' Sustainability Vol. 3 No. 8, pp. 1090-1113, 2001.

[15] E. Becker and T. Jahn, 'Soziale Ökologie:Grundzüge einer Wissenschaft von den gesellschaftlichen Naturverhältnissen' Frankfurt/New York, Campus, 2006.

[16] A. K. Giri 'The calling of a creative trans-disciplinary', Futures, Vol. 34, No. 1, pp. 103-15, 2002.

[17] T.W. Clark 'The Policy Process: A practical Guide for Natural Resource Professionals' New Haven/London, Yale University Press, 2002.

[18] G. Briscoe and C. Mulligan 'Digital Innovation: The Hackathon Phenomenon' Creative Works, 2004.

[19] S. Sousa 'Lessons learnt from a public-private big data hackathon' Big Innovation Centre Report, 2013.

[20] C. Pohl and G.H. Hadorn, 'Principles for Designing Trans-Disciplinary Research: Proposed by the Swiss Academies of Arts and Sciences' München, oekom Verlag, 2007.

[21] D. J. Lang, et al. 'Trans-disciplinary research in sustainability science: practice, principles, and challenges' Sustainability science, Vol. 7, No. 1, pp. 25-43, 2012.

[22] H, Lapp, S. Balla et al., " The 2006 NESCent Phyloinformatics Hackathon: Afield report" Evolutionary Bioinformatics online. Vol. 3, p. 287, 2007.

[23] R. T. Gabriela, Y.B. Kafai, A Barrie and T Orkan, "StitchFest: Diversifying a College Hackathon to Broaden Participation and Perceptions in Computing." Proceedings of the 46th ACM Technical Symposium on Computer Science Education. ACM, 2015.

[24] N. Linnell, S. Figueira, N. Chintala, L. Falzarano and V. Ciancio, "Hack for the homeless: A humanitarian technology hackathon," Global Humanitarian Technology Conference (GHTC), 2014 IEEE, San Jose, CA, 2014, pp. 577-584. doi: 10.1109/GHTC.2014.6970341

[25] E.A. Kolog, E. Sutinen, M. Vanhalakka-Ruoho,'Ecounseling implementation: Students' life stories and counseling technologies in perspective", International Journal of Education and Development using Information and Communication Technology (IJEDICT), Vol. 10, Issue 3, pp. 32-48, 2014.

\section{Authors' Profiles}

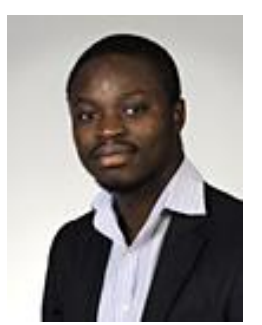

Awuni Emmanuel Kolog (MSc) received his Master`s degree in Computer Science from the University of Eastern Finland. $\mathrm{He}$ is currently a $\mathrm{PhD}$ Candidate at the same University. Emmanuel's research is mainly focused on using Natural Language Processing approach to extract, categorize and visualize emotions from Students` Life stories written in text by potential participants in order to form the basis to explore contextualized digital counseling platforms (digital games). His research interests span across contextualized e-counseling implementation, User-centered design, Natural Language Processing for emotion detection, Game design based on life stories, ICT4D and educational technologies. Emmanuel was the Teaching Assistant of the course (DT). 


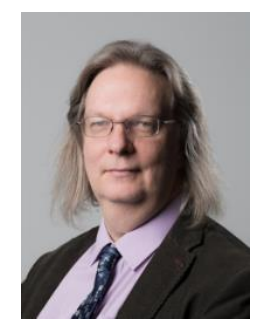

Prof. Erkki Sutinen (PhD) received his $\mathrm{PhD}$ in Computer Science from the University of Helsinki. He is the leader of the Interaction Design group at the University of Turku. He is also the founder of the EdTech research group at the University of Eastern Finland. He is a specialist in the field of educational technology and ICT for development. He is also the founder of international online $\mathrm{PhD}$ program: IMPDET at the University of Eastern Finland. Prof. Sutinen's research interests include technologies for special education, contextualized IT education, visual and textual tools for learning, and natural language processing methods for business intelligence and for emotion detection. For these, he supervises and collaborates with several $\mathrm{PhD}$ students and educational institutions. Prof. Erkki was the course (DT) professor.

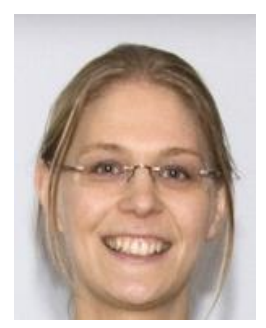

Eeva Nygren is currently a $\mathrm{PhD}$ student in Computer Science at the University of Eastern Finland. Her research in education technology aims at increasing motivation towards mathematics through educational games.

How to cite this paper: Emmanuel Awuni Kolog, Erkki Sutinen, Eeva Nygren,"Hackathon for Learning Digital Theology in Computer Science", International Journal of Modern Education and Computer Science(IJMECS), Vol.8, No.6, pp.1-12, 2016.DOI: 10.5815/ijmecs.2016.06.01 